\title{
Glucocorticoid Receptor Gene Polymorphisms and Potential Association to Chronic Obstructive Pulmonary Disease SusCEPTIBILITY AND SEVERITY
}

\author{
K. Schwabe, G. Vacca, R. Dück, A. Gillissen \\ St. George Medical Center, Robert-Koch-Hospital, Leipzig, Germany
}

\begin{abstract}
Objective: As chronic obstructive pulmonary disease (COPD) is known for poor glucocorticoid (GC) response, we hypothesized that polymorphic variants of the glucocorticoid receptor (GR) gene might predispose for COPD and/or disease severity.

Material and methods: Three out of about 50 of the most abundant receptor GR gene polymorphisms were investigated in a case-control study which included 207 patients with chronic bronchitis or COPD (mean FEV1 50.5\% predicted, GOLD I-IV) and 106 age matched healthy subjects (mean FEV1 101.8\% predicted). These were genotyped: a) for the N363S (Exon 2; $1220 \mathrm{~A}>\mathrm{G}(\mathrm{I})$ ); b) the BCLI restriction fragment length polymorphism (Intron 2; $647 \mathrm{C}>\mathrm{G}$ (II)); and c) the ER2223EK (Exon 2; 198, $200 \mathrm{G}>\mathrm{A}$ (III)), using RT-PCR and PCR-RFLP method on genomic DNA isolated from EDTA blood.

Results: Genotype distribution between COPD and healthy subjects were alike in all of these three polymorphisms. N363S was found in $0.94 \%$ of the healthy and $0 \%$ of the COPD subjects. BCLI was detected in $11.3 \%$ of the controls and $15.5 \%$ of the COPD patients whereas heterozygote frequency was less in the COPD (44.4\%) group (controls 60.4\%). ER2223EK lacks in any of the study subjects. Further, SNPs did not correlate with COPD severity stage (GOLD), exacerbation rates, and clinical course.

Conclusion: COPD is not linked to gene polymorphisms N363S, BCLI-RFLP, and ER2223EK. Since we analyzed only these 3 receptor gene polymorphisms, this study cannot rule out that other GR gene variants and linkages may be of influence.
\end{abstract}

Key words: polymorphisms, glucocorticoid receptor gene, COPD

\section{INTRODUCTION}

Chronic obstructive pulmonary disease (COPD) is one of the leading pulmonary diseases worldwide. The World Health Organization (WHO) estimates that, until 2020, COPD will be at fifth position of the most common diseases and at rank third in worldwide death statistics. Many details concerning the etiology, patho- mechanisms and factors deteriorating the disease are still unknown. Although exposition to cigarette smoke is a major risk factor for COPD development [1], it is unclear why only $10-20 \%$ of the smokers develop COPD [1] and why only $15 \%$ of the lung function deterioration of smokers can be related to quantity and duration of smoke exposition [2]. In the past, various factors have been elucidated being potentially responsible for this phenomenon. One of those factors may be genetically based since high susceptibility to enhanced cigarette smoke related lung function deterioration was observed among family members [3, 1]. The only known monogenetic factor to cause lung emphysema and COPD is the $\alpha 1$-antitrypsine $(\alpha 1$ AT). This deficiency is rare and found in only $1-2 \%$ of all COPD-cases, and by far does not account for the numerous COPD cases [4].

It is only partly understood, why COPD, in contrast to asthma, responds poorly long-term therapy with inhaled glucocorticosteroids (GC) [5]. Possibly, genetic factors may not only - at least in part - influence the development of COPD, but may also weaken the response to drugs such as GC and causing therapy resistance. Once COPD responses poorly to inhaled corticosteroids and many diseases have been associated with glucocorticosteroid (GC) resistance [6, 7, 8], we hypothesized that alterations in the $\mathrm{GC}$ receptor (GR) might be involved in individual susceptibility as well as contribute to disease severity.

\section{Material AND METHODS}

\section{STUDY DESIGN}

The study protocol was approved by the Ethics Committee of the State of Saxony, and written informed consent was obtained from all individuals prior to inclusion.

For this case control study, 207 patients with chronic bronchitis alone or with airway obstruction (= COPD) and 106 healthy age-matched controls were recruited during February 2004 and August 2005 in St. George Medical Center, Robert Koch Hospital, Leipzig and in two private practices in the cities Altenburg and Leipzig (Germany). Patients were includ- 
ed providing they had the following characteristics: chronic cough and mucus production according to WHO bronchitis definition [9], or suffering from COPD stage I to IV according to the definition of the Global Initiative for COPD (GOLD: FEV1 <80\% predicted or worse, FEV1/FVC $<70 \%$ ). Exclusion criteria were: acute COPD exacerbation during inclusion, asthma, allergies, and severe chronic disease from clinical significance according to the investigators judgment, other pulmonary diseases such as diffuse diseases of the lung parenchyma, as well as severe diseases such as cancer, instable disease condition other than COPD (e.g., coronary heart disease, chronic heart failure, kidney failure, liver diseases, infection diseases including acute tuberculosis, or immunodeficiency). Age, sex, body mass index (BMI), smoking habit, medical history and concomitant diseases were recorded using a standardized questionnaire. Instable COPD condition was defined as having three or more exacerbations or more requiring hospitalization and systemic medication (GC and/or antibiotics). Spirometry and blood gas analysis were performed in all patients and healthy volunteers.

\section{Genotyping Methods}

Genomic DNA was isolated from peripheral blood by standard extraction procedures (QIAamp ${ }^{\circledR}$ DNA Blood Mini Kit, Quiagen GmbH, Hilden, Germany). Polymorphisms N363S, ER2223EK, BCLI were detected after amplification by real-time polymerase chain reaction (Rotor Gene 3000). Table 1 presents the primer used for PCR amplification. $25 \mu \mathrm{l}$ of PCR sample contained $1 \mu \mathrm{l}$ extracted DNA, $1 \mu \mathrm{l}$ of each primer and fluorescent dye, 12,5 $\mu \mathrm{l}$ Taq DNA polymerase (Quiagen HotStarTaq ${ }^{\circledR}$ Master Mix Kit, Quiagen $\mathrm{GmbH}$, Hilden, Germany) and 7,5 $\mu$ l deionized water. Samples were incubated at first at $95^{\circ}$ for $15 \mathrm{~min}$, followed by 40 cycles of $95^{\circ} \mathrm{C}$ for $15 \mathrm{~s}$ and 58 or $60^{\circ} \mathrm{C}$ for $60 \mathrm{~s}$ and were finally cooled down by $25^{\circ}$ for 30 min.

Eight microliters of PCR product were digested with $1 \mu \mathrm{l}$ restriction enzyme and $6 \mu \mathrm{l}$ buffer (Tsp 509 for N363S, Mnl1 for ER2223EK and BCL1 for BCLI) (New England Biolabs GmbH, Frankfurt am Main, Germany) and transferred to $4 \%$ agarose gel elec- trophoresis. Products were visualized using ethidium bromide and ultraviolet illumination (see Fig. 1). About fifty samples were sequenced to verify the accuracy of our genotyping protocol.

\section{STATISTICAL ANALYSIS}

Patient's age, BMI, and FEV1 values were expressed as means \pm SD. Association of the GR gene polymorphism genotypes between COPD patients and healthy subjects were analyzed using the $\chi^{2}$ test for $3 \times 2$ contingency tables. The linkage between COPD severity and BMI, age, cumulative cigarette exposure (pack) years), and pulmonary function data were examined using ANOVA for normal distribution, and the Kruskal-Wallis test for heterogeneity respectively. Statistics were calculated using the SPSS software package version 12.0. Haplotype frequencies, linkage disequilibrium, and Hardy-Weinberg equilibrium were analyzed with the Arlequin software package 3.01 (Excoffier, 2006).

\section{RESULTS}

Table 2 shows the baseline characteristics of the two study populations: chronic bronchitis with (=COPD) or without ( $=$ chronic bronchitis) airway obstruction, and healthy volunteers.

Both groups were matched for age and smoking habits. Recruitment follows roughly a $2: 1$ (COPD vs. healthy volunteers) scheme. The study population followed the rules of the Hardy-Weinberg equilibrium. Taken this into account, allele frequencies of the polymorphic variant N363S AA:GG was $0.947: 0.053$, for BCLI CC:GG 0.61:0.39, and 0.971:0.029 for the polymorphism ER2223EK. Fig. 1 shows representative agarose gel electrophoresis of the PCR products from the three GR polymorphisms (COPD patients). Distribution of the genotypes between COPD patients and the control group were alike (Fig. 2 A-C). The three polymorphic variants were homogenously distributed among the different GOLD severity stages (no significant differences; Table 3). Furthermore, GR polymorphisms did not differ depending on disease stability vs. instability (unstable COPD $=$ at least 3 exacerbations, Fig. 2 D-F).

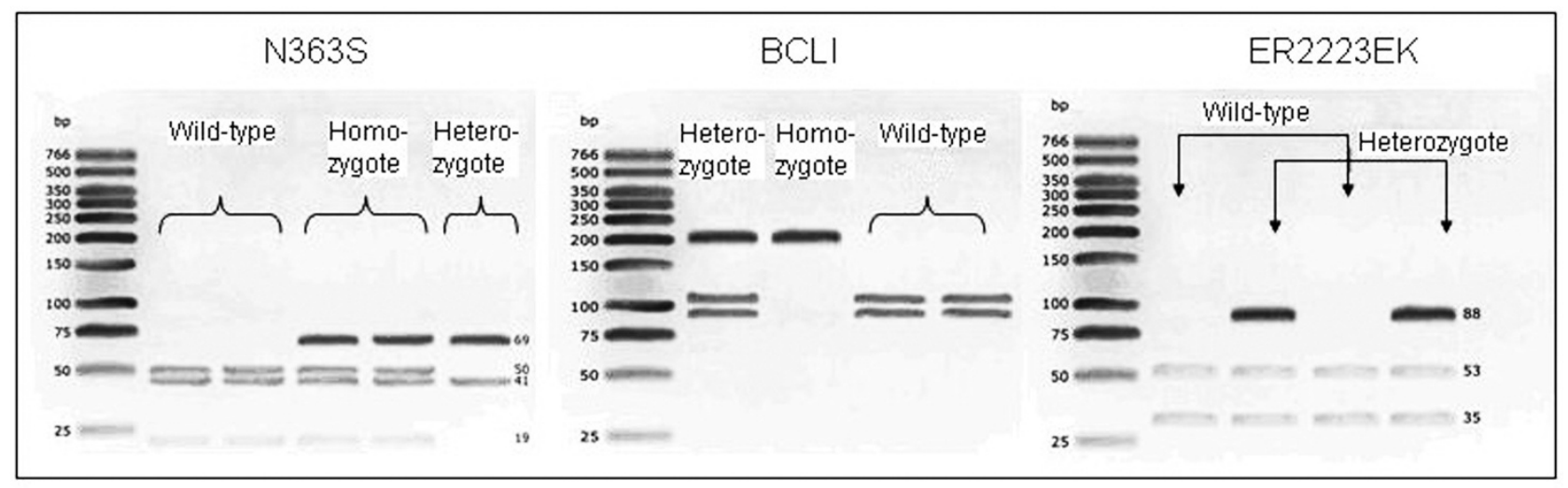

Fig.1. Identification of N363S, BCLI, and ER2223EK polymorphisms in selected COPD patients. In ER2223EK, no homozygote SNP carrier was found. 


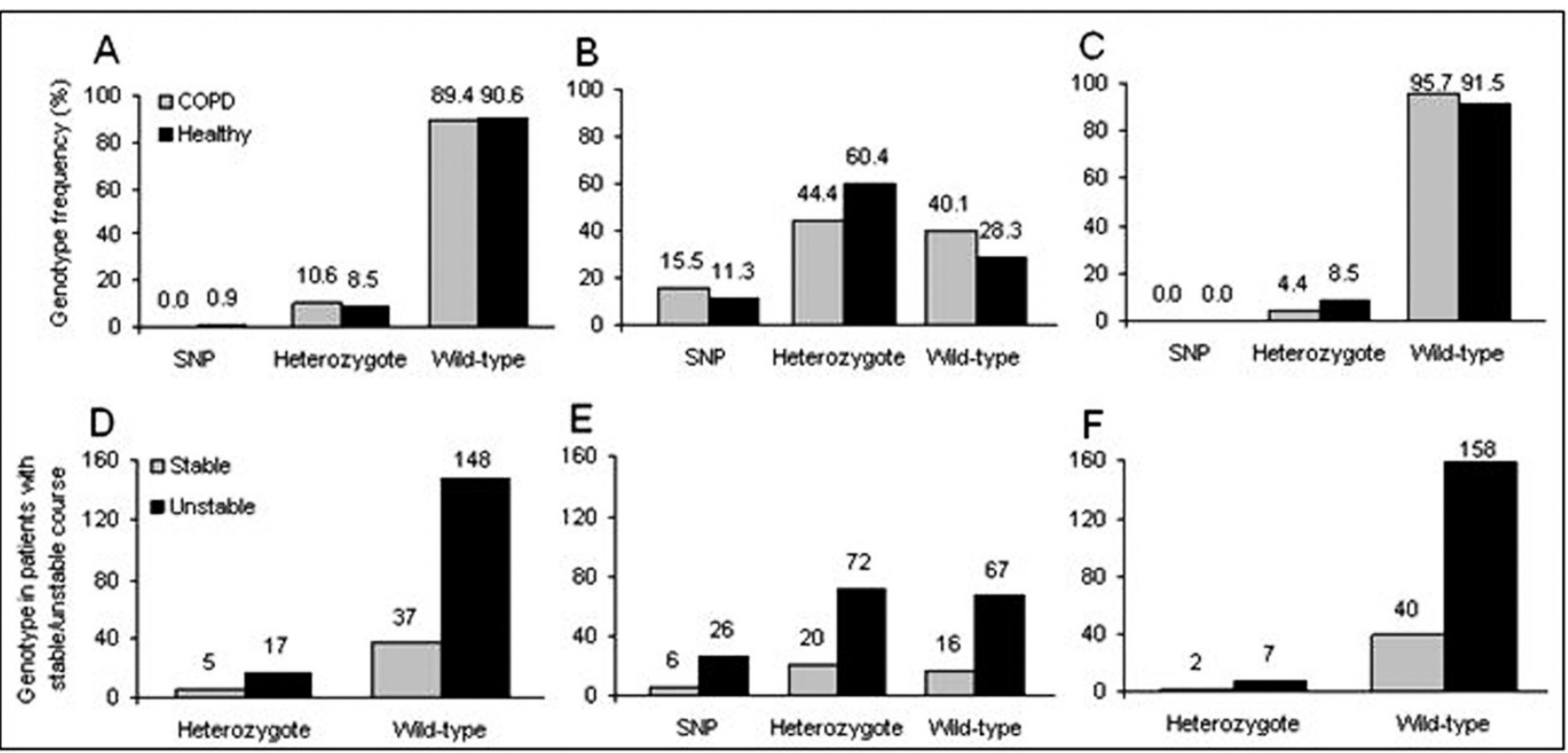

Fig. 2. Genotype distribution in COPD and healthy volunteers: A) N363S, B) BCLI, C) ER2223EK. Genotype distribution, in absolute terms, in COPD patients depending on disease stability (instable $\geq 3$ exacerbations): D) N363S, E) BCLI, F) ER2223EK. No significant differences were observed.

Table 1. Sequences of primers used in PCR.

\begin{tabular}{l|l|l}
\hline Polymorphism & Primer sense & Primer antisense \\
\hline N363S & 5’ CAA CAG CAG GAT CAG AAG CCT AT 3’ & 5’ CCC AGA GAA GTC AAG TTG TCA TCT C 3’ \\
\hline ER2223EK & 5' TCC AAA GAA TCA TTA ACT CCT GGT AGA 3’ & 5’ GCT CCT CCT CTT AGG GTT TTA TAG AAG 3’ \\
\hline BCLI & f 5 'GCA GTG AAC AGT GTA CCA GAC C 3` & 5`AAA TTG AAG CTT AAC AAT TTT GGC 3’ \\
\hline
\end{tabular}

Table 2. Baseline characteristics of COPD patients and healthy volunteers.

\begin{tabular}{|c|c|c|}
\hline Parameter & COPD & Healthy volunteers \\
\hline Patients/healthy volunteers (n) & 207 & 106 \\
\hline Age $( \pm S D)$ & $63.3 \pm 10.8$ & $63.9 \pm 11.1$ \\
\hline Sex (male : female) & $136: 71$ & $47: 59$ \\
\hline BMI & $26.5 \pm 0.5$ & $26.9 \pm 0.4$ \\
\hline FEV1 (l) & $1.4 \pm 0.7$ & $2.7 \pm 0.7$ \\
\hline FEV1 \%predicted & $50.5 \pm 20.2$ & $101.8 \pm 14.1$ \\
\hline FVC (l) & $2.5 \pm 0,9$ & $3.4 \pm 0.9$ \\
\hline FVC \%predicted & $69.9 \pm 19.1$ & $103.1 \pm 16.0$ \\
\hline FEV1/FVC & $57.8 \pm 14.0$ & $80.7 \pm 6.6$ \\
\hline GOLD classification of groups & & Not applicable \\
\hline 1. Chronic bronchitis n (\%) & $23(11.1)$ & \\
\hline 2. GOLD 1 n $(\%)$ & $8(3.9)$ & \\
\hline 3. GOLD 2 n $(\%)$ & $66(31.9)$ & \\
\hline 4. GOLD 3 n $(\%)$ & $50(24.2)$ & \\
\hline 5. GOLD 4 n $(\%)$ & $60(28.9)$ & \\
\hline
\end{tabular}


Table 3. Association of the N363S ( $p=0.878)$, BCLI ( $p=0.343)$, ER2223EK ( $p=0.966)$ and disease severity. No significant differences were observed between GOLD stages and those single nucleotide polymormphisms (SNPs).

\begin{tabular}{l|c|l|l|l}
\hline GOLD & & Wild-type & Heterozygote & Homozygote \\
\hline N363S Polymorphism - n (\%) \\
\hline Chronic bronchitis & 23 & $21(91.3)$ & $2(8.7)$ & $0(0.0)$ \\
GOLD I & 8 & $7(87.5)$ & $1(12.5)$ & $0(0.0)$ \\
GOLD II & 66 & $58(87.9)$ & $8(12.1)$ & $0(0.0)$ \\
GOLD III & 50 & $45(90.0)$ & $5(10.0)$ & $0(0.0)$ \\
GOLD IV & 60 & $54(90.0)$ & $6(10.0)$ & $0(0.0)$ \\
\hline BCLI Polymorphism- n (\%) & 23 & $9(39.1)$ & $11(47.8)$ & $3(13.0)$ \\
chronic bronchitis & 8 & $1(12.5)$ & $5(62.5)$ & $2(25.1)$ \\
GOLD I & 66 & $24(36.4)$ & $31(47.0)$ & $11(16.7)$ \\
GOLD II & 50 & $21(42.0)$ & $20(40.0)$ & $9(18.0)$ \\
GOLD III & 60 & $28(46.7)$ & $25(41.7)$ & $7(11.7)$ \\
GOLD IV & 60 & $58(96.7)$ & $2(3.3)$ & $0(0.0)$ \\
\hline ER2223EK Polymorphism-n $\%)$ & $0(0.0)$ \\
\hline chronic bronchitis & 23 & $23(100)$ & $0(0.0)$ & $0(0.0)$ \\
GOLD I & $7(87.5)$ & $1(12.5)$ & $0(0.0)$ \\
GOLD II & 66 & $63(95.5)$ & $3(4.6)$ & $0(0.0)$ \\
GOLD III & 50 & $47(94.0)$ & $3(6.0)$ & \\
GOLD IV & 60 &
\end{tabular}

\section{DiSCUSSION}

The GR gene is located on the long arm 31-32 of chromosome $5[10,11]$ and consists of a $110 \mathrm{~kb}$ region of 10 exons [12]. Up to 50 GR gene polymorphisms are known. Koyano et al [13] described about 50 polymorphisms of this gene which have been reported to be associated with altered sensitivity to GC. One of the therapeutic problems in COPD is the reduced sensitivity to steroids during the therapy which is also observed for various diseases such as rheumatoid arthritis, asthma and COPD [14]. Many of these SNPs have been reported to be associated with numerous diseases and disease severity [6]. N363S polymorphism is characterized by a nucleotide exchange of AAT $\rightarrow$ AGT at position 1220 leading to substitution of asparagine for serine [15]. As a result cellular sensitivity of GC increases [7]. BclI-polymorphism being located in the non-coding intron 2 and causing a nucleotide exchange of $\mathrm{C} \rightarrow \mathrm{G}$, is a commonly observed SNPs [6, 16]. Also this SNP has been associated with altered GR function resulting in either augmentation [17] or diminution of GC effectiveness [18]. In ER2223EK polymorphism, a nucleotide exchange of GAG $\rightarrow$ AAA at position 198 and 200 of the codons 198 and 200 , resulting in an amino acid exchange of arginine to lysine [19]. Also here, steroid suppression tests with dexamethasone revealed an enhanced GC resistance $[7,8]$.

Since GC function is somewhat dependent on alteration of the GR gene [18, 20-22], it seems rational to investigate the implication of possible SNPs in COPD, a disease known for poor GC response. This study investigates for the first time on a larger scale the association of GR-gene polymorphisms in COPD patients. For this work, we chose three of the most common polymorphic variants of the GR-gene. The allele frequencies of the polymorphic variants we found were in agreement with those reported in the literature $[17,23,24]$. However, our data excluded an association between the polymorphic variants and both COPD as a disease and COPD severity defined as elevated exacerbations rates. An analysis of subgroups, looking for cumulative cigarette smoke exposure, sex, and GOLD stages confirmed this negative result.

Our study has several limitations. For investigating a relationship between SNPs and disease characteristics, the overall patient number seems small. Since the SNPs frequency did not differ between COPD patients and our healthy control cohort, and because we did not even observed a trend, the lack of significance is not due to low group numbers. Due to practical reasons, we investigated only a small variety of possible GC-gene polymorphisms. Therefore, we cannot rule out that other SNPs might be more important for COPD development and/or disease severity. However, this case seems to be unlikely since the allele frequencies of these polymorphisms were found to be considerably lower in the screened populations, and there is only rare data about confirmed disease associations [6].

It is unlikely that a single gene polymorphism might have a significant impact on a multifactor disease, such as COPD [25]. The lack of any association between the SNPs we investigated in this study might, there- 
fore, be comprehensible, although other SNPs have been reported to be at least weakly linked to this disease such as polymorphisms of the $\beta 2$-adrenoreceptor gene $[26,27,28]$, the Matrix metalloproteinases (MMP)-genes [29], toll-like receptor genes or genes coding for xenobiotic-metabolizing enzymes like the microsomal epoxid hydrolase [30]. The only coherent genetic link to the development of a 'COPD-liked' disease is the $\alpha 1$-antitrypsin deficiency of which more than 100 genetic variations are known on chromosome $14[31,32]$.

Conflicts of interest: The authors declare no conflicts of interest in relation to this article.

\section{REFERENCES}

[1] Joos L, Pare PD, Sandford AJ. Genetic risk factors of chronic obstructive pulmonary disease. Swiss Med Wkly 2002; 132: 27-37.

[2] Mannino DM. Chronic obstructive pulmonary disease: definition and epidemiology. Respir Care 2003; 48: 1185-91.

[3] Barnes PJ. Genetics and pulmonary medicine. 9. Molecular genetics of chronic obstructive pulmonary disease. Thorax 1999; 54: 245-52.

[4] Lomas DA, Silverman EK. The genetics of chronic obstructive pulmonary disease. Respir Res 2001; 20-6.

[5] Barnes PJ, Pedersen S, Busse WW. Efficacy and safety of inhaled corticosteroids. New developments. Am J Respir Crit Care Med 1998; 157: 1-53.

[6] Bray PJ, Cotton RG. Variations of the human glucocorticoid receptor gene (NR3C1): pathological and in vitro mutations and polymorphisms. Hum Mutat 2003; 21: 557-68.

[7] De Lange P, Koper JW, Huizenga NA, Brinkmann AO, De Jong FH, Karl M, Chrousos GP, Lamberts SW. Differential hormone-dependent transcriptional activation and repression by naturally occurring human glucocorticoid receptor variants. Mol Endocrinol 1997; 11: 1156-64.

[8] Van Rossum EF, Koper JW, Huizenga NA, Uitterlinden AG, Janssen JA, Brinkmann AO, Grobbee DE, De Jong FH, Van Duyn CM, Pols HA, Lamberts SW. A polymorphism in the glucocorticoid receptor gene, which decreases sensitivity to glucocorticoids in vivo, is associated with low insulin and cholesterol levels. Diabetes 2002; 51: 3128-34.

[9] World Health Organisation. Report of an expert committee: Definition and diagnosis of pulmonary disease with special reference to chronic bronchitis and emphysema. Techn Rep Ser 1961; 213: 14-19.

[10] Theriault A, Boyd E, Harrap SB, Hollenberg SM, Connor JM. Regional chromosomal assignment of the human glucocorticoid receptor gene to $5 \mathrm{q} 31$. Hum Genet 1989; 83 : 289-91.

[11] Francke U, Foellmer BE. The glucocorticoid receptor gene is in 5q31-q32. Genomics 1989; 4: 610-2.

[12] Encio IJ, Detera-Wadleigh SD. The genomic structure of the human glucocorticoid receptor. J Biol Chem 1991; 266: 7182-8.

[13] Koyano S, Saito Y, Sai K, Kurose K, Ozawa S, Nakajima T, Matsumoto K, Saito H, Shirao K, Yoshida T, Mimami H, Ohtsu A, Saijo N, Sawada J. Novel genetic polymorphisms in the NR3C1 (glucocorticoid receptor) gene in a Japanese population. Drug Metab Pharmacokinet 2005; 20: 79-84.

[14] Bamberger CM, Schulte HM, Chrousos GP. Molecular determinants of glucocorticoid receptor function and tissue sensitivity to glucocorticoids. Endocr Rev 1996; 17: 245-61.
[15] Van Rossum EF, Voorhoeve PG, Te Velde SJ, Koper JW, Delemarre-Van De Waal HA, Kemper HC, Lamberts SW. The ER22/23EK polymorphism in the glucocorticoid receptor gene is associated with a beneficial body composition and muscle strength in young adults. J Clin Endocrinol Metab 2004; 89: 4004-9.

[16] Van Rossum EF, Koper JW, Van Den Beld AW, Uitterlinden AG, Arp P, Ester W, Janssen JA, Brinkmann AO, De Jong FH, Grobbee DE, Pols HA, Lamberts SW. Identification of the BclI polymorphism in the glucocorticoid receptor gene: association with sensitivity to glucocorticoids in vivo and body mass index. Clin Endocrinol Oxford 2003; 59: 585-92.

[17] Rosmond R, Chagnon YC, Holm G, Chagnon M, Perusse L, Lindell K, Carlsson B, Bouchard C, Bjorntorp P. A glucocorticoid receptor gene marker is associated with abdominal obesity, leptin, and dysregulation of the hypothalamic-pituitary-adrenal axis. Obes Res 2000; 8: 211-8.

[18] Panarelli M, Holloway CD, Fraser R, Connell JM, Ingram MC, Anderson NH, Kenyon CJ. Glucocorticoid receptor polymorphism, skin vasoconstriction, and other metabolic intermediate phenotypes in normal human subjects. J Clin Endocrinol Metab 1998; 83: 1846-52.

[19] Van Rossum EF, Lamberts SW. Polymorphisms in the glucocorticoid receptor gene and their associations with metabolic parameters and body composition. Recent Prog Horm Res 2004; 59: 333-57.

[20] Chikanza IC, Kozaci D, Chernajovsky Y. The molecular and cellular basis of corticosteroid resistance. J Endocrinol 2003; 179: 301-10.

[21] Huizenga NA, De Lange P, Koper JW, De Herder WW, Abs R, Kasteren JH, De Jong FH, Lamberts SW. Five patients with biochemical and/or clinical generalized glucocorticoid resistance without alterations in the glucocorticoid receptor gene. J Clin Endocrinol Metab 2000; 85: 2076-81.

[22] Koyano S, Saito Y, Nagano M, Maekawa K, Kikuchi Y, Murayama N, Fujino T, Ozawa S, Nakajima T, Matsumoto K, Saito H, Sawada J. Functional analysis of three genetic polymorphisms in the glucocorticoid receptor gene. J Pharmacol Exp Ther 2003; 307: 110-6.

[23] Buemann B, Vohl MC, Chagnon M, Chagnon YC, Gagnon J, Perusse L, Dionne F, Despres JP, Tremblay A, Nadeau A, Bouchard C. Abdominal visceral fat is associated with a BCLI restriction fragment lengtht polymorphism at the glucocorticoid receptor gene locus. Obes Res 1997; 5: 186-92.

[24] Koper JW, Stolk RP, De Lange P, Huizenga NA, Molijn G, Pols HA, Grobbee DE, Karl M, De Jong FH, Brinkmann AO, Lamberts SW. Lack of association between five polymorphisms in the human glucocorticoid receptor gene and glucocorticoid resistance. Hum Genet 1997; 99: 663-8.

[25] Lazarus R, Klimecki WT, Raby BA, Vercelli D, Palmer LJ, Kwiatkowski DJ, Silverman EK, Martinez F, Weiss ST. Genome-wide linkage analysis of severe, early-onset chronic obstructive pulmonary disease: airflow obstruction and chronic bronchitis phenotypes. Genomics 2005; 81:85-91.

[26] Vacca G, Schwabe K, Dück R, Hlawa H-P, Westphal A, Pabst S, Grohé C, Gillissen A. Polymorphisms of the B2 adrenoreceptor gene in chronic obstructive pulmonary disease. Ther Adv Respir Dis 2009; 3: 3-10.

[27] Hizawa N, Makita H, Nasuhara Y, Betsuyaku T, Itoh Y, Nagai K, Hasegawa M, Nishimura M. Beta2-adrenergic receptor genetic polymorphisms and short-term bronchodilator responses in patients with COPD. Chest 2007; 132: $1485-92$

[28] Matheson MC, Ellis JA, Raven J, Johns DP, Walters EH, Abramson MJ. Beta2-adrenergic receptor polymorphisms are associated with asthma and COPD in adults. J Hum Genet 2006; 51: 943-51. 
[29] Ito I, Nagai S, Handa T, Muro S, Hirai T, Tsukino M, Mishima M. Matrix metalloproteinase-9 promoter polymorphism associated with upper lung dominant emphysema. Am J Respir Crit Care Med 2005; 172: 1378-82.

[30] Smith CA, Harrison DJ. Association between polymorphism in gene for microsomal epoxide hydrolase and susceptibility to emphysema. Lancet 1997; 350: 630-3.

[31] Gillissen A, Schmidt EW, Rasche B, Ulmer WT. The biochemical behaviour of alpha1-antitrypsin under substitution therapy at homozygote (PI-ZZ) patients. KlinWschr 1989; 67: 328-35.

[32] Wencker M, Banik N, Buhl R, Seidel R. Konietzko N. Long-term treatment of alpha-1 antitrypsin deficiency-related pulmonary emphysema with human alpha-1 antitrypsin. Eur Respir J 1998; 11: 428-33.
Corresponding author:

Kristin Schwabe, M.D. and Adrian Gillissen, M.D., Ph.D.

St. Georg Medical Center, Robert-Koch-Hospital

(Director: Prof. Dr. A. Gillissen)

Nikolai-Rumjanzew-St. 100

04207 Leipzig

Germany

Phone: +493414231201

Fax: $\quad+493414231203$

E-mail: kristin.schwabe@web.de www.rkk-leipzig.de 